\title{
Lithological discontinuity in Glossic Planosols (Albeluvisols) of Lower Silesia (SW Poland)
}

\begin{abstract}
The paper focuses on Glossic Planosols (formerly Albeluvisols) with sandy topsoil widely represented in the northeastern part of Lower Silesia (SW Poland), in the range of tills from the Odra and Warta glaciations (Riss glaciation). The aim of the study was to characterize the texture of these soils in the context of the origin of parent materials and present-day pedogenic processes. Both the sedimentological and granulometric indexes, unbalances clay (and silt) fraction, and ventifact pavement at the contact of underlying loam and topsoil sandy layer confirm, that the textural differentiation of the topsoil and subsoil horizons has not resulted from the pedogenic processes, but primarily from the lithological discontinuity of glacial and post-glacial parent materials. Particle-size distribution and granulometric indexes of albeluvic tongues in the glossic horizon also confirm that the tongues has not been formed by eluviation of the fine fractions from the loamy material, but primarily by filling the initial thin crack with the sandy material. The coarser-textured tongues foster a deep infiltration and stagnation of water, and the development of reductic conditions allows further widening and deepening of the albeluvic tongues.
\end{abstract}

Keywords: Glossic Planosols, Albeluvisols, textural differentiation, lithological discontinuity

\section{INTRODUCTION}

Soil texture is a fundamental parameter determining soil properties and land use. An analysis of the particlesize distribution can provide a lot of information about genesis, litho- and pedogenetic processes, as well as taxonomic position of soil (Dobrzański et al. 1977, Kowalkowski and Borzyszkowski 1977, KoneckaBetley 1979, Mycielska-Dowgiałło 1980). Texture analysis is crucial in case of heterogeneous profiles of soils developed from stratified glacial deposits (Zagórski 2001). Frequently, the textural differentiation is often associated with lithological and facial changes of glacial deposits, as well as may develop under periglacial conditions (Goździk 1973, Manikowska 1997, Zagórski 1995, 1996). Recently, the lithological discontinuity within soil profile has been increasingly recognized in various typological units, particularly in the lowland clay-illuvial soils (Kühn 2003, Świtoniak 2008, van Ranst et al. 2011), as well as in the mountain Podzols (Waroszewski et al. 2013a, b) and Cambisols (Kacprzak and Derkowski 2007). Some researchers avoid to recognize the lithological discontinuity between eluvial and illuvial horizons of Luvisols and related soils, as they have insufficient arguments to distinguish primary lithological features from illuvial features. Pure pedological explanation of textural differentiation was the base for the concept of "loam sandification (spiaszczenie gliny)" that preceded the concept of clay illuviation ("lessivage"), but involved differentiation not only in clay but also in silt fractions (Konecka-Betley 1961, Szałata and Komisarek 2014).

Despite expected abundance, derived from geological and soil-agricultural maps (Kabała (ed.) 2015), lithological discontinuity in soils was rarely described in the lowland part of Lower Silesia, excluding stratification of alluvial soils ( Labaz et al. 2014). Meanwhile, it seems that in many soils classified previously as Albeluvisols (in Polish: gleby płowe zaciekowe spiaszczone), the large and abrupt vertical textural differentiation results from primary lithological stratification rather than from eluviation of fine fractions (Kabała (ed.) 2015).

The aim of the work was (1) to characterize the nature and origin of textural differentiation in profiles of clay-illuvial soils of north-eastern Lower Silesia and (2) to indicate the consequences of lithological discontinuity for soil naming and classification.

\section{MATERIAL AND METHODS}

The study focused on clay-illuvial soils (gleby płowe) displayed in the Polish soil-agricultural map as having significant textural diversity, e.g. sand texture in topsoil and loam in shallow subsoil, in the 
north-eastern part of Lower Silesia. More than 20 profiles were described and finally four representative ones are selected for this paper, as located in: the Oleśnicka Plain - profile 1 - Miłoszyce and profile 2 - Bielawa, the Twardogórskie Hills - profile 3 - Grabowno, and the Żmigrodzka Basin - profile 4 - Prusice (Fig. 1). The profiles Miłoszyce and Bielawa are located in a range of the Odra glaciation (the older Middle-Polish (Riss) glaciation, 300-230 ka), while the profiles Prusice and Grabowno are in the range of the Warta glaciation (the younger Middle-Polish (Riss) glaciation, 210-130 ka). During the Vistulian (the North-Polish (Würm) glaciation, 115-7.3 ka) severe periglacial conditions occurred in the area of Lower Silesia, which fostered the transport of sandy and silty materials, and enabled the accumulation of cover sands (Kondracki 2001, Manikowska 1997) and loess (Chlebowski and Linder 1991) of varying thickness. Soils were described and classified according to Polish Soil Classification (PSC 2011) and FAO-WRB classification (IUSS Working Group WRB 2015). In each of the distinguished soil horizons and subhorizons, soil samples were collected for laboratory analysis. In all soil profiles under investigation, the $\mathrm{E} / \mathrm{B}$ horizons with albeluvic tongues were present, typically for Albeluvisols (IUSS Working Group WRB 2006), in PSC (2011) called "gleby płowe zaciekowe". Thus, in the $\mathrm{E} / \mathrm{B}$ and $\mathrm{B} / \mathrm{E}$ horizons, samples were collected separately from the albeluvic tongues (abbrev. „tongues”) and from angular aggregates between tongues (,aggregates”, abbrev. ,aggreg.”), as well as bulk, mixed samples were collected from the whole horizon volume.

Particle-size distribution of the fine earths $(<2 \mathrm{~mm})$ was conducted using sand separation on sieves and the hydrometer method for silt and clay fractions, after sample dispersion with hexametaphosphate-bicarbonate, according to the standard PN-R-04032. The names of texture classes were given according to classification of Polish Society of Soil Science (Polskie Towarzystwo Gleboznawcze 2009) and the USDA classification (Schoeneberger et al. 2012), with an indication of dominant sand sub-fraction (Table 1 and 2).

Based on the distribution of sand and silt fractions and subfractions, a set of granulometric indices proposed by Kowalkowski and Prusinkiewicz (1963) was calculated, as well as other indices suggested by the WRB to be diagnostic for lithological discontinuity (IUSS Working Group WRB 2015). These include the following ratios (Table 4): fine sand to medium sand (A), fine sand + very fine sand to medium sand (B), fine sand to coarse sand (C), fine sand + coarse silt to coarse + medium sand (D), medium + fine + very fine sand to coarse sand (E), very fine sand to medium sand (F), and very fine sand to fine sand $(\mathrm{G})$. For the comprehensive characteristics, the sedimen-

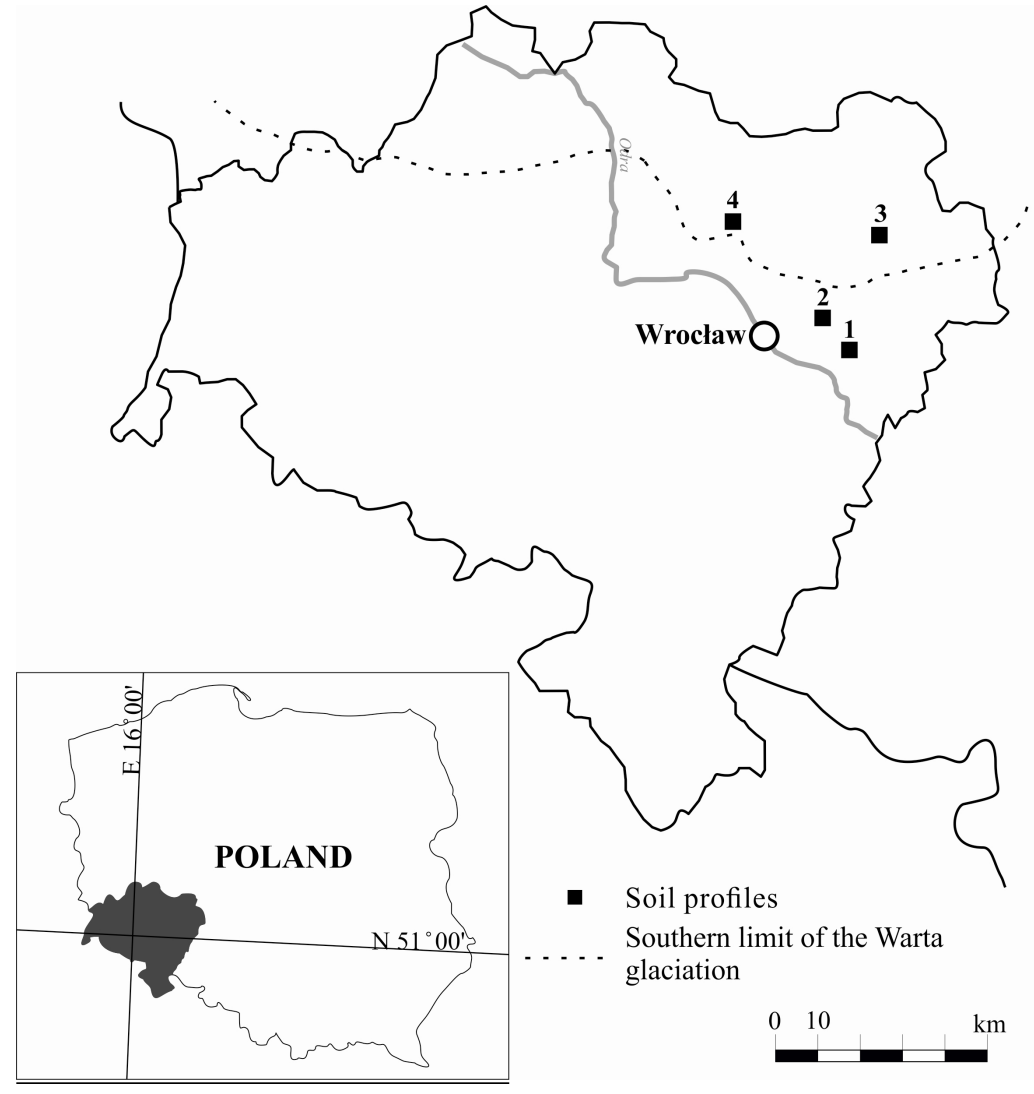

FIGURE 1. Location of soil profiles within study area. Profile designations: 1 - Miłoszyce, 2 Bielawa, 3 - Grabowno, and 4 - Prusice 
TABLE 1. Particle-size distribution of the soils under study

\begin{tabular}{|c|c|c|c|c|c|c|c|c|c|c|c|c|c|c|}
\hline \multirow[t]{2}{*}{ Profile } & \multirow{2}{*}{$\begin{array}{l}\text { Soil } \\
\text { horizon }\end{array}$} & \multirow{2}{*}{$\begin{array}{l}\text { Depth } \\
\text { (cm) }\end{array}$} & \multicolumn{10}{|c|}{ Particle-size (mm) distribution (\%) } & \multicolumn{2}{|c|}{ Texture class } \\
\hline & & & $>2.0$ & $2.0-1.0$ & $1.0-0.5$ & $0.5-0.25$ & $0.25-0.1$ & $0.1-0.05$ & $0.05-0.02$ & $0.02-0.006$ & $0.006-0.002$ & $<0.002$ & PTG & USDA \\
\hline \multirow{5}{*}{$\begin{array}{l}\text { Profile } 1 \text { - } \\
\text { Miłoszyce } \\
\text { (arable soil) }\end{array}$} & $\mathrm{Ap}$ & $0-26$ & 2 & 3 & 11 & 23 & 32 & 12 & 6 & 9 & 1 & 3 & $\mathrm{pg}$ & LFS \\
\hline & Ap2 & $26-35$ & 5 & 3 & 10 & 22 & 32 & 11 & 6 & 12 & 1 & 3 & $\mathrm{pg}$ & LFS \\
\hline & $\mathrm{E}$ & $35-52$ & 2 & 3 & 10 & 21 & 32 & 15 & 5 & 6 & 4 & 4 & $\mathrm{pg}$ & LFS \\
\hline & $2 \mathrm{E} / \mathrm{Btg}$ & $\begin{array}{c}52-80 \\
\text { tongues }\end{array}$ & $\begin{array}{l}1 \\
1\end{array}$ & $\begin{array}{l}1 \\
1\end{array}$ & $\begin{array}{l}3 \\
3\end{array}$ & $\begin{array}{l}10 \\
20\end{array}$ & $\begin{array}{l}27 \\
47\end{array}$ & $\begin{array}{l}15 \\
11\end{array}$ & $\begin{array}{r}11 \\
2\end{array}$ & $\begin{array}{l}8 \\
5\end{array}$ & $\begin{array}{l}3 \\
0\end{array}$ & 22 & gpi & $\begin{array}{l}\text { SCL } \\
\text { LFS }\end{array}$ \\
\hline & $2 \mathrm{Btg} / \mathrm{E}$ & $\begin{array}{c}\text { tongues } \\
80-100 \\
100-130\end{array}$ & $\begin{array}{l}0 \\
1 \\
1\end{array}$ & $\begin{array}{l}0 \\
1 \\
1 \\
\end{array}$ & $\begin{array}{l}2 \\
2 \\
2\end{array}$ & $\begin{array}{r}29 \\
11 \\
9 \\
\end{array}$ & $\begin{array}{l}56 \\
31 \\
38\end{array}$ & $\begin{array}{r}6 \\
11 \\
17 \\
\end{array}$ & $\begin{array}{l}3 \\
8 \\
7\end{array}$ & $\begin{array}{r}1 \\
10 \\
6 \\
\end{array}$ & $\begin{array}{l}1 \\
1 \\
1\end{array}$ & $\begin{array}{c}2 \\
25 \\
19\end{array}$ & $\begin{array}{l}\mathrm{pl} \\
\mathrm{gpi} \\
\mathrm{gp}\end{array}$ & $\begin{array}{l}\text { FS } \\
\text { SCL } \\
\text { FSL } \\
\end{array}$ \\
\hline \multirow{5}{*}{$\begin{array}{l}\text { Profile } 2 \text { - } \\
\text { Bielawa } \\
\text { (arable soil) }\end{array}$} & Ap & $0-38$ & 1 & 1 & 7 & 27 & 44 & 7 & 3 & 6 & 2 & 3 & $\mathrm{ps}$ & FS \\
\hline & $\underline{E}$ & $38-50$ & 3 & 1 & 8 & 30 & 42 & 9 & 1 & 4 & 2 & 3 & ps & FS \\
\hline & 2E/Btg & $\begin{array}{r}50-80 \\
\text { aggreg. }\end{array}$ & $\begin{array}{l}1 \\
1\end{array}$ & $\begin{array}{l}1 \\
0\end{array}$ & $\begin{array}{l}4 \\
1\end{array}$ & $\begin{array}{r}12 \\
5\end{array}$ & $\begin{array}{l}28 \\
32\end{array}$ & $\begin{array}{l}14 \\
13\end{array}$ & $\begin{array}{l}6 \\
7\end{array}$ & $\begin{array}{l}7 \\
8\end{array}$ & $\begin{array}{l}4 \\
3\end{array}$ & $\begin{array}{l}24 \\
31\end{array}$ & $\begin{array}{l}\text { gpi } \\
\text { gpi }\end{array}$ & $\begin{array}{l}\text { SCL } \\
\text { SCL }\end{array}$ \\
\hline & & tongues & 1 & 1 & 6 & 17 & 33 & 17 & 4 & 4 & 2 & 16 & $\mathrm{gp}$ & FSL \\
\hline & $2 \mathrm{Btg}$ & $\begin{array}{c}80-90 \\
100-105 \\
120-125 \\
140-145 \\
\end{array}$ & $\begin{array}{l}2 \\
2 \\
2 \\
1 \\
\end{array}$ & $\begin{array}{l}1 \\
1 \\
1 \\
1 \\
\end{array}$ & $\begin{array}{l}5 \\
8 \\
5 \\
5 \\
\end{array}$ & $\begin{array}{l}11 \\
13 \\
11 \\
10 \\
\end{array}$ & $\begin{array}{l}24 \\
22 \\
26 \\
27 \\
\end{array}$ & $\begin{array}{r}14 \\
9 \\
10 \\
10 \\
\end{array}$ & $\begin{array}{r}5 \\
11 \\
11 \\
10 \\
\end{array}$ & $\begin{array}{r}10 \\
8 \\
8 \\
9 \\
\end{array}$ & $\begin{array}{l}2 \\
2 \\
3 \\
3 \\
\end{array}$ & $\begin{array}{l}28 \\
26 \\
25 \\
25 \\
\end{array}$ & $\begin{array}{l}\text { gpi } \\
\text { gpi } \\
\text { gpi } \\
\text { gpi }\end{array}$ & $\begin{array}{l}\text { SCL } \\
\text { SCL } \\
\text { SCL } \\
\text { SCL } \\
\end{array}$ \\
\hline \multirow{5}{*}{$\begin{array}{l}\text { Profile } 3- \\
\text { Grabowno } \\
\text { (forest soil) }\end{array}$} & A & $\begin{array}{l}0-6 \\
6-12\end{array}$ & $\begin{array}{l}5 \\
6\end{array}$ & $\begin{array}{l}4 \\
4\end{array}$ & $\begin{array}{r}8 \\
10\end{array}$ & $\begin{array}{l}21 \\
25\end{array}$ & $\begin{array}{l}34 \\
36\end{array}$ & $\begin{array}{r}17 \\
9\end{array}$ & $\begin{array}{l}9 \\
7\end{array}$ & $\begin{array}{l}3 \\
3\end{array}$ & $\begin{array}{l}2 \\
2\end{array}$ & $\begin{array}{l}2 \\
4\end{array}$ & $\begin{array}{l}\mathrm{pg} \\
\mathrm{pg}\end{array}$ & $\begin{array}{l}\text { LFS } \\
\text { LFS }\end{array}$ \\
\hline & $\mathrm{E}$ & $\begin{array}{l}12-24 \\
24-40\end{array}$ & $\begin{array}{l}6 \\
8 \\
\end{array}$ & $\begin{array}{l}5 \\
4 \\
\end{array}$ & $\begin{array}{l}9 \\
9 \\
\end{array}$ & $\begin{array}{l}23 \\
23 \\
\end{array}$ & $\begin{array}{l}38 \\
39 \\
\end{array}$ & $\begin{array}{l}7 \\
9\end{array}$ & $\begin{array}{l}5 \\
3 \\
\end{array}$ & $\begin{array}{l}8 \\
9 \\
\end{array}$ & $\begin{array}{l}1 \\
1\end{array}$ & $\begin{array}{l}4 \\
3 \\
\end{array}$ & $\begin{array}{l}\mathrm{pg} \\
\mathrm{pg}\end{array}$ & $\begin{array}{l}\text { LFS } \\
\text { LFS }\end{array}$ \\
\hline & 2E/Btg & $\begin{array}{c}40-62 \\
\text { tongues }\end{array}$ & $\begin{array}{l}2 \\
4 \\
\end{array}$ & $\begin{array}{l}1 \\
2 \\
\end{array}$ & $\begin{array}{l}5 \\
5 \\
\end{array}$ & $\begin{array}{l}13 \\
15 \\
\end{array}$ & $\begin{array}{l}32 \\
40 \\
\end{array}$ & $\begin{array}{l}13 \\
18 \\
\end{array}$ & $\begin{array}{l}9 \\
6 \\
\end{array}$ & $\begin{array}{l}9 \\
2 \\
\end{array}$ & $\begin{array}{l}3 \\
2 \\
\end{array}$ & $\begin{array}{l}15 \\
10 \\
\end{array}$ & $\begin{array}{l}\text { gl } \\
\mathrm{pg}\end{array}$ & $\begin{array}{l}\text { FSL } \\
\text { LFS }\end{array}$ \\
\hline & $2 \mathrm{Btg} / \mathrm{E}$ & $\begin{array}{r}\text { aggreg. } \\
62-85\end{array}$ & $\begin{array}{l}1 \\
1\end{array}$ & $\begin{array}{l}1 \\
2\end{array}$ & $\begin{array}{l}4 \\
7\end{array}$ & $\begin{array}{l}10 \\
18\end{array}$ & $\begin{array}{l}24 \\
36\end{array}$ & $\begin{array}{l}14 \\
13\end{array}$ & $\begin{array}{l}8 \\
6\end{array}$ & $\begin{array}{l}8 \\
2\end{array}$ & $\begin{array}{l}4 \\
6\end{array}$ & $\begin{array}{l}27 \\
10\end{array}$ & $\begin{array}{l}\text { gpi } \\
\text { gp }\end{array}$ & $\begin{array}{l}\text { SCL } \\
\text { FSL }\end{array}$ \\
\hline & $2 \mathrm{Btg}$ & $85-110$ & 1 & 0 & 4 & 10 & 21 & 13 & 9 & 11 & 5 & 27 & gpi & SCL \\
\hline \multirow{6}{*}{$\begin{array}{l}\text { Profile } 4 \text { - Prusice } \\
\text { (forest - postarable } \\
\text { soil) }\end{array}$} & Ap & $0-26$ & 2 & 3 & 14 & 41 & 32 & 3 & 1 & 2 & 2 & 2 & $\mathrm{pl}$ & MS \\
\hline & $\mathrm{AE}$ & $26-35$ & 2 & 2 & 10 & 41 & 36 & 3 & 1 & 4 & 2 & 1 & $\mathrm{pl}$ & MS \\
\hline & $\underline{E}$ & $35-58$ & 3 & 2 & 10 & 41 & 34 & 7 & 2 & 2 & 0 & 2 & $\mathrm{pl}$ & MS \\
\hline & 2E/Btgx & $58-63$ & 1 & 1 & 7 & 22 & 25 & 9 & 10 & 8 & 3 & 15 & $\mathrm{gl}$ & SL \\
\hline & 2E/Btg & $\begin{array}{c}63-75 \\
\text { tongues }\end{array}$ & $\begin{array}{l}1 \\
0 \\
\end{array}$ & $\begin{array}{l}0 \\
1 \\
\end{array}$ & $\begin{array}{l}4 \\
5 \\
\end{array}$ & $\begin{array}{l}14 \\
23 \\
\end{array}$ & $\begin{array}{l}20 \\
43 \\
\end{array}$ & $\begin{array}{r}9 \\
13 \\
\end{array}$ & $\begin{array}{r}13 \\
2 \\
\end{array}$ & $\begin{array}{r}14 \\
5 \\
\end{array}$ & $\begin{array}{l}5 \\
0 \\
\end{array}$ & $\begin{array}{r}21 \\
8 \\
\end{array}$ & $\begin{array}{l}\text { gpi } \\
\text { pg }\end{array}$ & $\begin{array}{l}\text { SCL } \\
\text { LFS }\end{array}$ \\
\hline & 2Btg & $\begin{array}{l}\text { aggreg. } \\
75-115\end{array}$ & $\begin{array}{l}0 \\
0\end{array}$ & $\begin{array}{l}0 \\
0\end{array}$ & $\begin{array}{l}2 \\
1\end{array}$ & $\begin{array}{l}7 \\
5\end{array}$ & $\begin{array}{l}14 \\
22\end{array}$ & $\begin{array}{l}10 \\
14\end{array}$ & $\begin{array}{l}21 \\
17\end{array}$ & $\begin{array}{l}16 \\
15\end{array}$ & $\begin{array}{l}2 \\
3\end{array}$ & $\begin{array}{l}28 \\
23\end{array}$ & $\begin{array}{l}\text { gi } \\
\text { gz }\end{array}$ & $\begin{array}{l}\mathrm{CL} \\
\mathrm{L}\end{array}$ \\
\hline
\end{tabular}


TABLE 2. Percentage of sand sub-fractions in the soils under study

\begin{tabular}{|c|c|c|c|c|c|c|c|c|}
\hline \multirow{2}{*}{$\begin{array}{l}\text { Profile } \\
\text { Horizon }\end{array}$} & \multirow{2}{*}{$\begin{array}{l}\text { Soil } \\
\text { Depth }\end{array}$} & \multicolumn{6}{|c|}{ Percentage of sand sub-fraction (diameter in mm) } & \multirow[t]{2}{*}{ Class } \\
\hline & & $\mathrm{cm}$ & $2.0-1.0$ & $1.0-0.5$ & $0.5-0.25$ & $0.25-0.1$ & $0.1-0.05$ & \\
\hline \multirow{5}{*}{$\begin{array}{l}\text { Profile } 1 \text { - } \\
\text { Miłoszyce }\end{array}$} & Ap & $0-26$ & 4 & 14 & 28 & 40 & 14 & $\mathrm{f}$ \\
\hline & Ap2 & $26-35$ & 4 & 13 & 28 & 41 & 14 & $\mathrm{f}$ \\
\hline & $\mathrm{E}$ & $35-52$ & 4 & 12 & 26 & 40 & 18 & $\mathrm{f}$ \\
\hline & 2E/Btg & $\begin{array}{c}52-80 \\
\text { tongues }\end{array}$ & $\begin{array}{l}2 \\
1 \\
\end{array}$ & $\begin{array}{l}5 \\
4 \\
\end{array}$ & $\begin{array}{l}18 \\
24 \\
\end{array}$ & $\begin{array}{l}48 \\
57 \\
\end{array}$ & $\begin{array}{l}27 \\
14 \\
\end{array}$ & $\begin{array}{l}f \\
f\end{array}$ \\
\hline & $2 \mathrm{Btg} / \mathrm{E}$ & $\begin{array}{c}\text { tongues } \\
80-100 \\
100-130 \\
\end{array}$ & $\begin{array}{l}0 \\
2 \\
2 \\
\end{array}$ & $\begin{array}{l}2 \\
4 \\
3 \\
\end{array}$ & $\begin{array}{l}31 \\
20 \\
13 \\
\end{array}$ & $\begin{array}{l}60 \\
55 \\
57 \\
\end{array}$ & $\begin{array}{r}7 \\
19 \\
25 \\
\end{array}$ & $\begin{array}{l}f \\
f \\
f\end{array}$ \\
\hline \multirow{4}{*}{$\begin{array}{l}\text { Profile } 2 \text { - } \\
\text { Bielawa }\end{array}$} & Ap & $0-38$ & 1 & 8 & 31 & 51 & 9 & $\mathrm{f}$ \\
\hline & $\underline{E}$ & $38-50$ & 1 & 9 & 33 & 47 & 10 & $\mathrm{f}$ \\
\hline & $2 \mathrm{E} / \mathrm{Btg}$ & $\begin{array}{l}50-80 \\
\text { aggreg. } \\
\text { tongues }\end{array}$ & $\begin{array}{l}2 \\
0 \\
1\end{array}$ & $\begin{array}{l}7 \\
2 \\
8\end{array}$ & $\begin{array}{l}20 \\
10 \\
23 \\
\end{array}$ & $\begin{array}{l}47 \\
63 \\
45 \\
\end{array}$ & $\begin{array}{l}24 \\
25 \\
23 \\
\end{array}$ & $\begin{array}{l}f \\
f \\
f\end{array}$ \\
\hline & 2Btg & $\begin{array}{c}80-90 \\
100-105 \\
120-125 \\
140-145\end{array}$ & $\begin{array}{l}2 \\
2 \\
2 \\
2\end{array}$ & $\begin{array}{r}9 \\
15 \\
9 \\
9\end{array}$ & $\begin{array}{l}20 \\
25 \\
21 \\
19\end{array}$ & $\begin{array}{l}44 \\
42 \\
49 \\
51\end{array}$ & $\begin{array}{l}25 \\
16 \\
19 \\
19\end{array}$ & $\begin{array}{l}f \\
f \\
f\end{array}$ \\
\hline \multirow[t]{5}{*}{$\begin{array}{l}\text { Profile } 3 \text { - } \\
\text { Grabowno }\end{array}$} & A & $\begin{array}{l}0-6 \\
6-12\end{array}$ & $\begin{array}{l}5 \\
5 \\
\end{array}$ & $\begin{array}{l}10 \\
12 \\
\end{array}$ & $\begin{array}{l}25 \\
30\end{array}$ & $\begin{array}{l}40 \\
43\end{array}$ & $\begin{array}{l}20 \\
10\end{array}$ & $\begin{array}{l}f \\
f\end{array}$ \\
\hline & $\mathrm{E}$ & $\begin{array}{l}12-24 \\
24-40 \\
\end{array}$ & $\begin{array}{l}6 \\
5 \\
\end{array}$ & $\begin{array}{l}11 \\
11 \\
\end{array}$ & $\begin{array}{l}28 \\
27 \\
\end{array}$ & $\begin{array}{l}46 \\
46 \\
\end{array}$ & $\begin{array}{r}9 \\
11 \\
\end{array}$ & $\begin{array}{l}f \\
f\end{array}$ \\
\hline & 2E/Btg & $\begin{array}{c}40-62 \\
\text { tongues }\end{array}$ & $\begin{array}{l}2 \\
3 \\
\end{array}$ & $\begin{array}{l}8 \\
6 \\
\end{array}$ & $\begin{array}{l}20 \\
19\end{array}$ & $\begin{array}{l}50 \\
50\end{array}$ & $\begin{array}{l}20 \\
22\end{array}$ & $\begin{array}{l}f \\
f\end{array}$ \\
\hline & $2 \mathrm{Btg} / \mathrm{E}$ & $\begin{array}{l}\text { aggreg. } \\
62-85 \\
\end{array}$ & $\begin{array}{l}2 \\
3 \\
\end{array}$ & $\begin{array}{l}8 \\
9 \\
\end{array}$ & $\begin{array}{l}19 \\
24\end{array}$ & $\begin{array}{l}45 \\
47 \\
\end{array}$ & $\begin{array}{l}26 \\
17 \\
\end{array}$ & $\begin{array}{l}f \\
f\end{array}$ \\
\hline & $2 \mathrm{Btg}$ & $85-110$ & 0 & 8 & 21 & 44 & 27 & $\mathrm{f}$ \\
\hline \multirow{6}{*}{$\begin{array}{l}\text { Profile } 4 \text { - } \\
\text { Prusice }\end{array}$} & Ap & $0-26$ & 3 & 15 & 44 & 34 & 4 & $\mathrm{~m}$ \\
\hline & $\mathrm{AE}$ & $26-35$ & 2 & 11 & 45 & 39 & 3 & $\mathrm{~m}$ \\
\hline & $\mathrm{E}$ & $35-58$ & 2 & 11 & 44 & 36 & 7 & $\mathrm{~m}$ \\
\hline & 2E/Btgx & $58-63$ & 2 & 11 & 34 & 39 & 14 & $\mathrm{f}$ \\
\hline & $2 \mathrm{E} / \mathrm{Btg}$ & $\begin{array}{c}63-75 \\
\text { tongues }\end{array}$ & $\begin{array}{l}0 \\
1\end{array}$ & $\begin{array}{l}9 \\
6 \\
\end{array}$ & $\begin{array}{l}30 \\
27\end{array}$ & $\begin{array}{l}43 \\
51\end{array}$ & $\begin{array}{l}18 \\
15\end{array}$ & $\begin{array}{l}f \\
f\end{array}$ \\
\hline & $2 \mathrm{Btg}$ & $\begin{array}{l}\text { aggreg. } \\
75-115\end{array}$ & $\begin{array}{l}0 \\
0\end{array}$ & $\begin{array}{l}6 \\
3\end{array}$ & $\begin{array}{l}21 \\
12\end{array}$ & $\begin{array}{l}42 \\
52\end{array}$ & $\begin{array}{l}31 \\
33\end{array}$ & $\begin{array}{l}f \\
f\end{array}$ \\
\hline
\end{tabular}

Explanation: $\mathrm{f}$ - fine, $\mathrm{m}$ - medium; aggreg. - structural aggregates, tongues - albeluvic tongues.

tological indexes according to Folk and Ward (1957) were calculated, both in original linear scale (in $\mu \mathrm{m}$ ), and after conversion to the phi scale, using the formula $\varphi=-\log 2 \mathrm{~d}$, where $\mathrm{d}$ is the particle diameter in mm (Krumbein 1964).

\section{RESULTS}

\section{Basic morphological properties}

The soils under investigation are clearly vertically differentiated in terms of their morphology and texture (Table 1). The humus horizons have a thickness from $12 \mathrm{~cm}$ (forest soils) up to $38 \mathrm{~cm}$ (arable soils).
Directly below the humus horizon, the layer is preserved that meets the requirements for an eluvial horizon, extending down to the depth of 40-58 cm (Table 1), with oximorphic mottles or iron-manganese concentrations in its bottom part. Horizons A and E have a sandy texture, with similar distribution of particular sand fractions in A and E horizons. The contact of eluvial and illuvial horizons is clearly marked in all profiles; "clear" or "abrupt" in terms of morphological terminology, even if its continuity is broken by interfingering of eluvial material into an illuvial one. Also, the abrupt contact between eluvial and illuvial (genetic) horizons is an abrupt transition between sandyand loamy-textured layers. Moreover, the disconti- 
nuous line of cobbles and coarse gravels, a residuum of former "moraine pavement" occur at the contact of underlying loam and overlying sand. At least some of the stones are ventifacts, i.e. have a double-sided polished upper part, clear effect of eolian process under harsh periglacial conditions. Loamy $2 \mathrm{E} / \mathrm{Btg}$, $2 \mathrm{Btg} / \mathrm{E}$, and $2 \mathrm{Btg}$ horizons meet criteria for argic diagnostic horizon, because of abundant clay cutans present on the aggregate surfaces and in the larger pores in the loamy part of horizons (clay cutans or bridges are absent in albic material of the tongues). Also, at least some subhorizons of the loamy subsoil fulfil criteria of the fragic horizon, due to high density and massive structure (PSC 2011). Moreover, glossic horizon $(2 \mathrm{E} / \mathrm{Btg})$ was recognized in the upper part of loamy layer in all profiles under investigation. Glossic horizon is featured by numerous tongues similar in colour to the eluvial horizon (E) and coarser in texture as compared to surrounding loamy Bt horizon. The boundaries between $2 \mathrm{E} / \mathrm{Btg}, 2 \mathrm{Btg} / \mathrm{E}$, and $2 \mathrm{Btg}$ are unclear and contractual, as the density of tongues penetrating into the $\mathrm{Bt}$ horizon changes gradually and irregularly down to the depth of more than $100-120 \mathrm{~cm}$. Both the glossic and argic/fragic horizons have strong stagnic properties, with redox mottles covering up to $100 \%$ of the exposed soil matrix (as the sum of reductimorphic and oximorphic colours).

\section{Sedimentological features of soil material}

The upper horizons $(A+E)$ are featured by a much larger average diameters of grains (mean $M$ range 142-171 $\mu \mathrm{m}$, geometric mean dg range 99-121 $\mu \mathrm{m}$ ), compared to the subsoil horizons (especially 2Bt), where the values of $\mathrm{M}$ and dg greatly decrease to about $22 \mu \mathrm{m}$. Average grain diameter in albeluvic tongues is higher than in the surrounding $2 \mathrm{E} / \mathrm{Btg}$ horizon, and, in particular, than in 2Btg (Table 3). Horizons $\mathrm{A}+\mathrm{E}$ and $2 \mathrm{Btg}$ differ in degree of sorting ratio (index $\mathrm{W}$ and $\mathrm{W} \varphi$ ). According to the sedimentological terminology, the grains in the A+E horizons are poorly sorted $(\mathrm{W} \varphi=2.0)$, and in the underlying loam are very poorly and extremely poorly sorted (2Btg horizons: $\mathrm{W} \varphi$ about 3.7). The other confirmation of different sorting degree is the kurtosis (indexes $\operatorname{Sp}$ and $\operatorname{Sp} \varphi$ ), which is leptokurtic (1.6-2.0) in topsoil and platykurtic (range 0.6-0.8) in 2Bt horizons. The diversity of kurtosis values is a result of unimodal particle-size distribution in $\mathrm{A}+\mathrm{E}$ horizons (due to absolute dominance of sand fraction) and bimodal distribution in $2 \mathrm{Bt}$ horizons (a relatively high content of sand and clay fractions, at low content of silt, Table 1). The skewness is positively skewed $(\mathrm{Sk} \varphi=0.3)$ in $\mathrm{A}+\mathrm{E}$ horizons, and strongly positively skewed $(\operatorname{Sk} \varphi=0.4-0.5)$ in 2E/Btg, albeluvic tongues, and 2Btg horizons (Table 3). Positive skewness indicates importance of the grains finer than average diameter.

Significant differences in the average diameter of grains, and in sorting ratios are interpreted by sedimentologists as sufficient indicators of different sedimentation environments and different kind of sediments (Racinowski et al. 2001). However, in soils impacted by lessivage, that interpretation cannot be applied directly, due to the pedogenic differentiation driven by clay translocation. Nevertheless, huge differences between the indicators' values (Table 3) in the topsoil and subsoil cannot arise only from the lessivage process, but at least in part are resulting from the primary lithological discontinuity between soil layers under comparison (Schülli-Maurer et al. 2007, Jaworska et al. 2014).

TABLE 3. Sedimentological indices according to Folk and Ward (1957) for the unified horizons of the soils under study

\begin{tabular}{|c|c|c|c|c|c|c|c|c|c|}
\hline \multirow{2}{*}{$\begin{array}{l}\text { Soil } \\
\text { horizon }\end{array}$} & M & W & Sk & $\mathrm{Sp}$ & \multirow[t]{2}{*}{$\mathrm{M} \varphi$} & \multirow[t]{2}{*}{$\mathrm{W} \varphi$} & \multirow[t]{2}{*}{$\operatorname{Sk} \varphi$} & \multirow[t]{2}{*}{$\operatorname{Sp} \varphi$} & \multirow{2}{*}{$\begin{array}{l}\mathrm{dg} \\
(\mu \mathrm{m})\end{array}$} \\
\hline & \multicolumn{4}{|l|}{$(\mu \mathrm{m})$} & & & & & \\
\hline \multirow[t]{2}{*}{ A } & $142 *$ & 4.2 & -0.3 & 1.6 & 3.0 & 2.0 & 0.3 & & \\
\hline & $50-261 * *$ & 2.9-6.5 & $-0.3-(-0.2)$ & $1.3-1.8$ & $1.9-4.3$ & $1.5-2.7$ & $0.2-0.3$ & $1.3-1.8$ & $41-175$ \\
\hline \multirow[t]{2}{*}{ E } & 171 & 3.8 & -0.3 & 1.7 & 2.7 & 1.9 & 0.3 & & \\
\hline & $54.5-241$ & $2.4-6.6$ & $-0.4-(-0.3)$ & $1.2-1.8$ & $2.1-4.2$ & $1.2-2.7$ & $0.3-0.4$ & $1.2-1.8$ & $45-179$ \\
\hline \multirow[t]{2}{*}{ 2E/Btg } & 41.6 & 10.6 & -0.5 & & 4.7 & & 0.5 & & \\
\hline & $23.5-64.3$ & $8.6-12.5$ & $-0.5-(-0.3)$ & $0.7-1.8$ & $4.0-5.4$ & $3.1-3.6$ & $0.3-0.5$ & $0.7-1.8$ & $25-65$ \\
\hline \multirow[t]{2}{*}{ Tongues } & 84.2 & 5.6 & -0.4 & 2.0 & 3.7 & 2.3 & 0.4 & 2.0 & \\
\hline & $38.6-146$ & $2.2-11.0$ & $-0.6-0.1$ & $1.7-2.3$ & $2.8-4.7$ & $1.1-3.5$ & $0.1-0.6$ & $1.7-2.3$ & $41-95$ \\
\hline \multirow[t]{2}{*}{ 2Btg } & 22.4 & 12.8 & -0.4 & 0.7 & 5.5 & 3.7 & 0.4 & 0.7 & 22 \\
\hline & $17.5-26.2$ & $10.0-14.6$ & $-0.5-(-0.4)$ & $0.6-0.8$ & $5.3-5.8$ & $3.3-3.9$ & $0.4-0.5$ & $0.6-0.8$ & $19-26$ \\
\hline
\end{tabular}

Explanation: *mean; **range (minimum-maximum); M - mean grain size; $\mathrm{W}$ - standard deviation; Sk - skewness; Sp - graphic kurtosis; $\mathrm{dg}$ - geometric mean grain size. 


\section{Particle-size distribution and texture classes}

The A+E horizons have a texture of sand and loamy sand, at variable content of silt fraction (5-20\%), and low content of clay fraction, below $4 \%$ (Fig. 2). Sub-fraction of fine sand (32-45\%) followed by medium sand (21-30\%) dominate among sand fractions in these horizons (Table 2). The order of sand sub-fractions is different in the profile Prusice only, where medium sand prevails above the fine sand (Table 2). The illuvial horizons (2Btg) most frequently have a texture of sandy clay loam (Fig. 2) in bulk (mixed) samples, whereas the texture of aggregates collected separately from the tongues is always finer and qualifies to clay loam class (Table 1, Prusice profile). In the illuvial horizons (2Btg) in all of the soils under investigation (including the profile Prusice), the fine sand predominates (up to 38\%), followed by medium sand $(22 \%)$. The albeluvic tongues have a texture of sand to sandy loam (Fig. 2), but generally, the texture class is more similar to this in topsoil rather than that in 2Btg horizon (Fig. 3). Surprisingly, the texture of tongues is sometimes coarser than in the eluvial horizon (profile Miłoszyce, tongues in $2 \mathrm{Btg} / \mathrm{E}$ horizon). It must be clearly stated, that the particlesize distribution reported for $2 \mathrm{Btg}$ and in particular for $2 \mathrm{E} / \mathrm{Btg}$ horizons is an average for loamy soil matrix (aggregates) and albeluvic tongues. If the density (abundance) of tongues is higher, the averaged particlesize distribution of glossic horizon is more closely related to eluvial than to illuvial horizon (Fig. 3 ACD).

Another consequence of albeluvic tonguing in $2 \mathrm{Btg}$ horizon is the difficulty in describing the gradient of clay content in the illuvial horizon. The expected decrease of clay content with depth is clearly visible in the profile Bielawa (featured by low intensity of albeluvic tonguing) and invisible in the Prusice profile (at high intensity of tonguing in 2E/Btg, 2Btg, and 2Btg horizons), where it even looks like a clay increase downward the soil profile (Table 1).

\section{Relative granulometric indexes}

The relative granulometric indexes used for evaluation of the lithological discontinuity are based on the proportion of sand and silt (sub-)fractions, which are considered not vulnerable to eluvial/illuvial processes (Kowalkowski and Prusinkiewicz 1963). The granulometric indexes calculated in this study have very different values in particular soil horizons (Table 4). Quantitative proportions of fine sand to medium sand (index A), fine sand plus very fine sand to medium sand (B), and fine sand plus coarse silt to coarse sand plus medium sand (D) were at least two times lower in topsoil A+E horizons (A: 1.3-1.4; B: 1.7-1.8; D: 1.3-1.5) than in 2Btg horizons (A: 2.6; B: 3.9; D: 3.8). The ratio of fine sand to coarse sand (index C) showed similar values throughout soil profiles (C: 2.6-3.2), and only in albeluvic tongues the index value was 6.3 that is two times higher than in surrounding $2 \mathrm{E} / \mathrm{Btg}$ and $2 \mathrm{Btg}$ horizons. Also the values of granulometric indexes recommended by the WRB classification (IUSS Working Group WRB 2015) differ significantly between $\mathrm{A}+\mathrm{E}$ and $2 \mathrm{Btg}$ horizons (Table 4 ), in particular with $\mathrm{F}$ index (the proportion of very fine sand to fine sand).

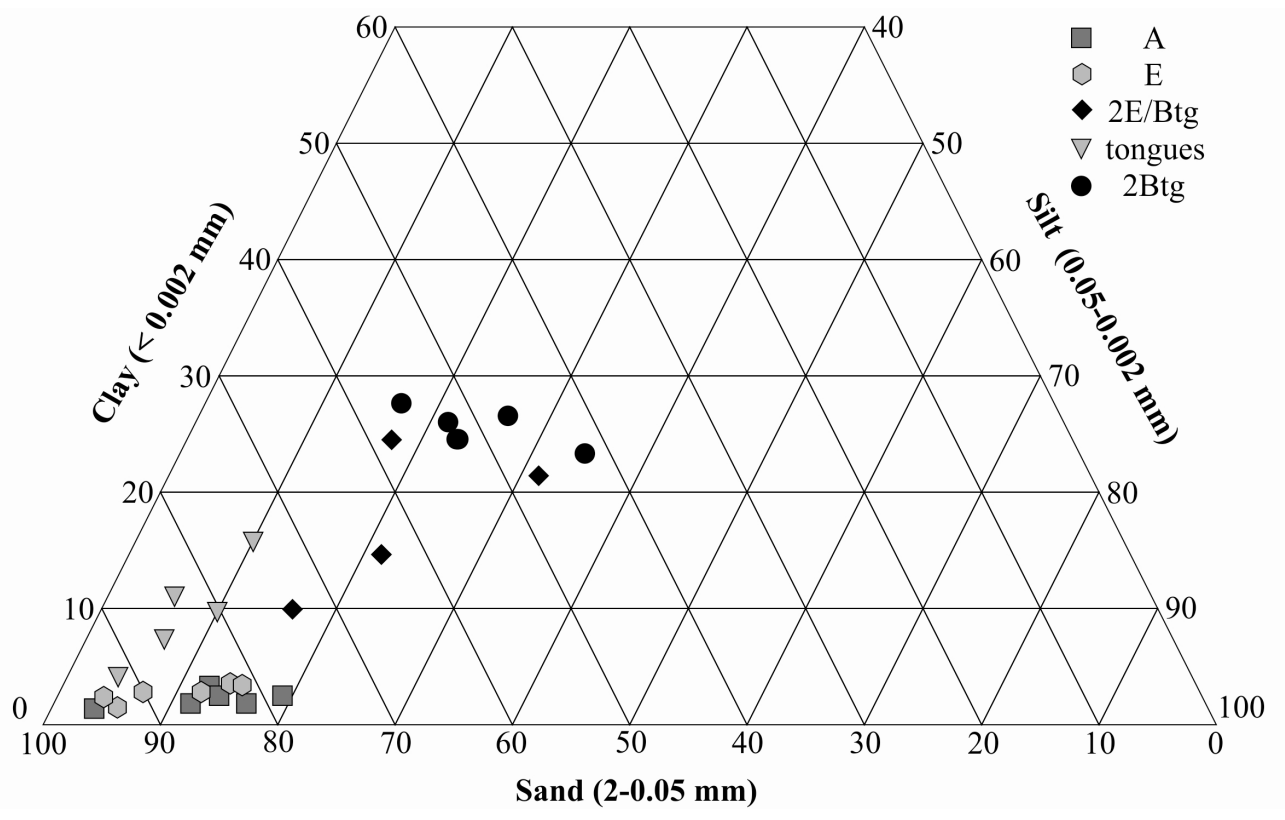

FIGURE 2. Graphical display of the texture of soil horizons under study 


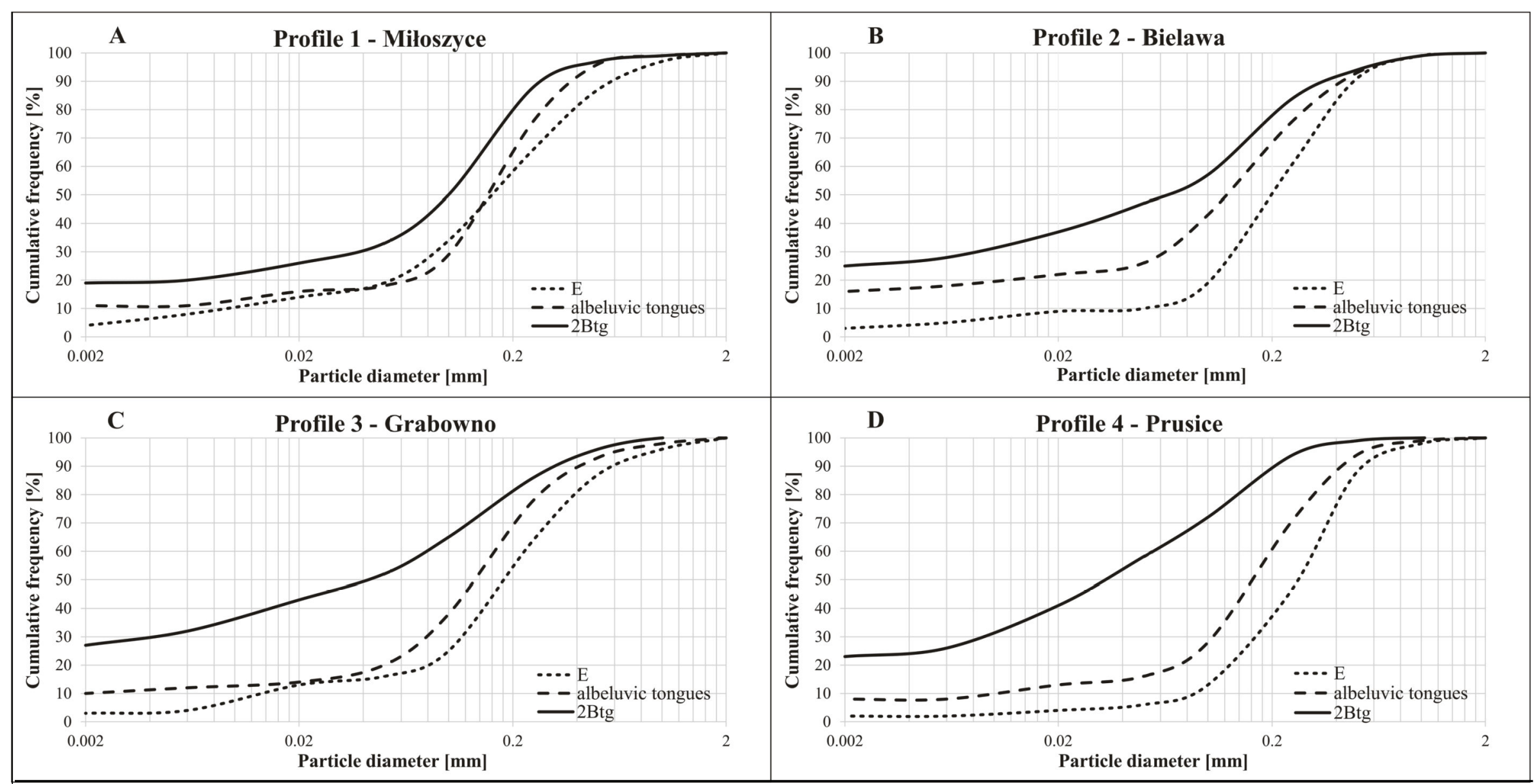

FIGURE 3. Cumulative texture curves for $\mathrm{E}$ and 2Btg horizons and albeluvic tongues in glossic horizon 


\section{DISCUSSION}

The data presented in this paper confirm that the textural differentiations in the profiles of soils developed from glacial materials in the north-eastern part of Lower Silesia meet the criteria for lithological discontinuity. The horizons $\mathrm{A}+\mathrm{E}$ (in other profiles, not included in this paper, also $\mathrm{ABv}$ and $\mathrm{AE}$ horizons) have a texture of sand with minimum clay content, whereas $2 \mathrm{Bt}$ horizons $(2 \mathrm{E} / \mathrm{Bt}$ and $2 \mathrm{Bt} / \mathrm{E})$ have a texture of loam, most frequently sandy clay loam. The albeluvic tongues in glossic $2 \mathrm{E} / \mathrm{Bt}$ horizons contain much coarser material than the surrounding loamy aggregates. Textural differentiations influence the physical and water properties, as well as the agricultural value of the soils. The thicker cover sand layer, the larger are negative consequences for water storage potential and soil fertility (Marcinek and Komisarek 2004, Glina et al. 2013). According to the Polish Soil Classification (2011) most of profiles meet the criteria for lessive soils with glossic horizon and thick sand layer in topsoil (gleby płowe zaciekowe spiaszczone). FAO-WRB has formerly classified these soils as Albeluvisols (IUSS Working Group WRB 2006), but presently the soils belong to Glossic Planosols (IUSS Working Group WRB 2015).

The origin of the textural differentiation in "podzolic" soils (until 60 s of $20^{\text {th }}$ century the clay illuvial soils and podzols have not been distinguished in Poland) has long been disputed in Poland. Some of the researchers explain this as related to pedogenic processes (lessivage) only and exclude a lithological discontinuity (Komisarek and Szałata 2008), highlighting i.a. domination of the same fine sand sub-fraction throughout the soil profile. However, the other facts argue for lithological discontinuity as the primary cause of textural differentiation.

The first argument for the lithological discontinuity is an unbalanced content of silt and clay fractions in the "eluvial" and "illuvial" horizons. The balance was calculated based on the content of clay in the "parent material", i.e. in the loam of the bottom profile (occurring below the depth of $100 \mathrm{~cm}$ ). If we assume that the entire profile had initially a texture of the loam in the parent material, we can calculate the stocks of illuvial clay in Bt horizons and stocks of clay "removed" from (or lacking in) topsoil horizons (taking into account the current clay content, thickness of horizons, and soil bulk density in these horizons). In most cases, the hypothetically eluviated amount of clay is up to two times higher than the stocks of illuvial clay in Bt horizons. Selective erosion of clay fraction (removal out of the soil profile) is theoretically possible (Kühn et al. 2006), but it may occur in cultivated topsoil only, and the selective clay erosion from the layer of $50 \mathrm{~cm}$ thick seems impossible, especially in the plain area. Even more difficult to explain is the low content of silt fraction in $\mathrm{A}+\mathrm{E}$ horizons. Illuvial horizons of soil under study are not enriched in silt, as compared to parent material. Thus, the loss of silt fraction in $\mathrm{A}+\mathrm{E}$ horizons is not reflected by its translocation to Bt horizons in course of pedogenic process. Such a large decrease of silt content may only result from selective water or wind erosion, but, as stated above, such a selective erosion from the layer of 50 $\mathrm{cm}$ thick is questionable. Moreover, loss of silt or clay

TABLE 4. Granulometric indices according to Kowalkowski and Prusinkiewicz (1963) and WRB (IUSS Working Group WRB, 2015) for the unified horizons of the soils under study

\begin{tabular}{|c|c|c|c|c|c|c|c|}
\hline \multirow{4}{*}{$\begin{array}{l}\text { Soil } \\
\text { Horizon }\end{array}$} & \multicolumn{7}{|c|}{ Index symbol } \\
\hline & A & $\mathrm{B}$ & $\mathrm{C}$ & $\mathrm{D}$ & $\mathrm{E}$ & $\mathrm{F}$ & $\mathrm{G}$ \\
\hline & \multicolumn{7}{|c|}{ Ratio of fractions } \\
\hline & $\begin{array}{l}0.25-0.1 / \\
0.5-0.25\end{array}$ & $\begin{array}{l}0.25-0.05 / \\
0.5-0.25\end{array}$ & $\begin{array}{l}0.25-0.1 / \\
1.0-0.5\end{array}$ & $\begin{array}{l}0.25-0.02 / \\
1-0.25\end{array}$ & $\begin{array}{l}0.5-0.05 / \\
1-0.5\end{array}$ & $\begin{array}{l}0.1-0.05 \\
0.5-0.25\end{array}$ & $\begin{array}{l}0.1-0.05 \\
0.25-0.1\end{array}$ \\
\hline $\mathrm{A}$ & $\begin{array}{l}1.4^{*} \\
0.8^{-1.6} 6^{* *}\end{array}$ & $\begin{array}{l}1.8 \\
0.9-2.4\end{array}$ & $\begin{array}{l}2.7 \\
2.1-3.9\end{array}$ & $\begin{array}{l}1.5 \\
0.7-2.1\end{array}$ & $\begin{array}{l}7.5 \\
5.4-11.1\end{array}$ & $\begin{array}{l}0.4 \\
0.1-0.8\end{array}$ & $\begin{array}{l}0.3 \\
0.1-0.5\end{array}$ \\
\hline $\mathrm{E}$ & $\begin{array}{l}1.3 \\
0.8-1.7\end{array}$ & $\begin{array}{l}1.7 \\
1.0-2.2\end{array}$ & $\begin{array}{l}3.2 \\
2.1-4.1\end{array}$ & $\begin{array}{l}1.3 \\
0.8-1.7\end{array}$ & $\begin{array}{l}8.1 \\
6.8-10.1\end{array}$ & $\begin{array}{l}0.3 \\
0.1-0.7\end{array}$ & $\begin{array}{l}0.2 \\
0.1-05\end{array}$ \\
\hline $2 \mathrm{E} / \mathrm{Btg}$ & $\begin{array}{l}1.9 \\
1.1-2.5\end{array}$ & $\begin{array}{l}2.7 \\
1.5-3.5\end{array}$ & $\begin{array}{l}3.0 \\
2.6-3.5\end{array}$ & $\begin{array}{l}2.4 \\
1.5-3.0\end{array}$ & $\begin{array}{l}10.7 \\
8.0-13.5\end{array}$ & $\begin{array}{l}0.8 \\
0.4-1.2\end{array}$ & $\begin{array}{l}0.4 \\
0.4-0.5\end{array}$ \\
\hline tongues & $\begin{array}{l}.2 \\
1.9-2.7\end{array}$ & $\begin{array}{l}2.9 \\
2.1-3.9\end{array}$ & $\begin{array}{l}6.3 \\
2.8-14.5\end{array}$ & $\begin{array}{l}2.5 \\
2.1-3.2\end{array}$ & $\begin{array}{l}22.6 \\
11.2-45.5\end{array}$ & $\begin{array}{l}0.7 \\
0.2-1.2\end{array}$ & $\begin{array}{l}0.3 \\
0.1-0.5\end{array}$ \\
\hline $2 \mathrm{Btg}$ & $\begin{array}{l}2.6 \\
1.7-4-4\end{array}$ & $\begin{array}{l}3.9 \\
2.4-7.2\end{array}$ & $\begin{array}{l}2.6 \\
1.6-5.0\end{array}$ & $\begin{array}{l}3.8 \\
2.0-8.8\end{array}$ & $\begin{array}{l}14.4 \\
5.5-41.0\end{array}$ & $\begin{array}{l}1.3 \\
0.7-2.8\end{array}$ & $\begin{array}{l}0.5 \\
0.4-06\end{array}$ \\
\hline
\end{tabular}

Explanation: *mean; **range (minimum-maximum). 
fraction resulting from the surface water or wind erosion is not a pedogenic, but a lithogenic process (Mycielska-Dowgiałło 1980, Manikowska 1997, Jaworska et al. 2014).

The second argument for the lithological discontinuity are significant differences and changes in relative values of the granulometric indexes. Although the fine sand fraction dominates throughout the profiles in the most of soils under investigation, the proportions of this fraction to other "stable" sand fractions (as medium and coarse sand fractions) are different in "eluvial" and "illuvial" horizons (Table 4; indexes A, B, D, E, F), whereas the ratios of particular sub-fractions of quartzitic sand cannot differentiate in course of lessivage (Schülli-Maurer et al. 2007, Van Ranst et al. 2011). FAO-WRB classification (IUSS Working Group WRB 2015) requires at least $5 \%$ of absolute and $25 \%$ of relative difference in compared fractions as the criterion for lithological discontinuity. The differences found in soils under investigation are much larger: the absolute differences are two-three times higher than the required minimum, and the relative differences often exceed $100 \%$. The lower values of the granulometric indexes in the sandy topsoil indicate the relatively coarser sand fraction in topsoil as compared to loamy subsoil. This difference can only be explained by different sedimentological conditions or different source material for the topsoil and subsoil layers (Mycielska-Dowgiałło 1980).

The third argument for the lithological discontinuity in the analyzed profiles, crucial for researchers who study the Pleistocene sediments and landforms, is the presence of eolized pavement at the contact of sand and till layers. On the one hand, the pavement testifies for the strong erosion of the former topsoil layer (former loamy eluvial horizon?) that led to accumulation of the most coarse fragment on the soil surface. On the other hand, the polished surfaces of the pavement cobbles testify for a long-term existence of the stone layer at land surface, because only the fully exposed stones and gravels could be specifically (two-sided) polished by wind. Therefore, the cover sand was deposited after a certain period of time after the pavement formation and wind polishing. The other stones and gavels spread throughout the till (below the pavement) do not have remarks of wind erosion. It must be stated that the single polished stones (ventifacts) are spread above the pavement line, in the overlying sand layer or even on the soil surface, transported there by upfreezing (Goździk and French 2004). This observation explains why a pavement layer at the contact of a till and cover sand is not continuous, or even poorly visible in some profiles.
Granulometric indexes are also useful in an explaining of the origin of albeluvic tongues in Glossic Planosols under study. Most of the indexes in tongues significantly differ from their values for Bt horizons (especially B, C, E, F indexes; Table 4). This means that the clay eluviation has not been the main process in the formation of tongues, because it would not change the proportions between the stable sand factions. At least in part, the tongues were formed by filling the thin cracks with sandy material from the overlying layer. The complete explanation of the tongues formation is still impossible based on the present data, but the specific texture of the tongue in $2 \mathrm{Btg} / \mathrm{E}$ horizon of Miłoszyce profile (Table 2) might indicate that some cracks were open on the soil surface under periglacial conditions that allowed their filling with eolian sand, much better segregated than the latter cover sand (different contents and ratios of almost all particle-size fractions). A similar phenomenon, but on a much larger scale, has been described by Dzierżek and Stańczuk (2006).

It was noticed during the fieldwork that the texture of albeluvic tongues is differentiated in the cross-section, which impeded soil sampling for laboratory analysis. The innermost part of the tongues is filled with sandy material, whereas the outer part at the contact with the soil aggregates is in fact a bleached hypocoating. It seems that the "true" sand tongues have much lesser thickness than it is considered based on colour differentiation of the soil mass. The seasonal inflow and stagnation of (surface) water in tongue creates reducing conditions and allows migration of reduced iron, and the development of bleached (reduced) hypocoatings on the surface of soil aggregates adjacent to the tongue (Lindbo et al. 2000). Thus, the present-day redox phenomena may cause continuous morphological thickening and vertical extending of the albeluvic tongues (Szymański et al. 2011). Also, the clay eluviation or decay cannot be excluded in these reduced soil zones (Kühn et al. 2006).

\section{CONCLUSIONS}

1. Both the sedimentological and granulometric indexes testify for the textural difference between the sandy "eluvial" horizons (sand and loamy sand classes) and loamy "illuvial" horizons (sandy clay loam class) of the Glossic Planosols in Lower Silesia does not originate from pedogenic processes, but is a kind of primary lithological discontinuity.

2. The layer of eolized pavement (consisting of polished gravels and cobbles - ventifacts) on the contact of till and overlying sand indicates, that the cover sand 
was settled on previously eroded loamy soil, for a certain period of time exposed at land surface for a wind erosion under periglacial conditions of the arctic desert.

3. The albeluvic tongues in Bt horizons were not formed exclusively by clay eluviation from the loamy soil, but at least in part by filling the thin cracks with sandy material. Presently, the thickness and depth of albeluvic tongues may grow due to water stagnation and redox phenomena.

4. Both the lithological discontinuity and unbalanced clay (and silt) content (in "eluvial" and "illuvial" horizons) indicate a multi-step polygenetic origin of the Glossic Planosols in SW Poland which requires a further explanation.

\section{ACKNOWLEDGMENT}

The study was financed by the National Science Centre of Poland (research grant 2012/05/B/NZ9/ 03389).

\section{REFERENCES}

Chlebowski R., Lindner L., 1991. Żródła materiału i warunki akumulacji lessów młodszych Wyżyny Małopolskiej. Biuletyn Geologiczny. WG UW, 32: 15-50 (In Polish).

Dobrzański B., Konecka-Betley K., Czępińska-Kamińska D., 1977. Procesy kształtowania się gleb wytworzonych z glin zwałowych Wysoczyzny Siedleckiej. Zeszyty Naukowe SGGW-AR w Warszawie, Rolnictwo 16: 9-24 (In Polish).

Dzierżek J., Stańczuk D., 2006. Record and palaeogeographical implications of Pleistocene periglacial processes in the Drohiczyn Plateau, Podlasie Lowland (Eastern Poland). Geological Quarterly 50(2): 219-228.

Folk R.L., Ward W., 1957. Brazos River Bar: A study in the significance of grain size parameters. Journal of Sedimentary Petrology 27: 3-26.

Glina B., Jezierski P., Kabała C., 2013. Physical and water properties of Albeluvisols in the Silesian Lowland (SW Poland). Soil Science Annual 64(4): 123-129.

Goździk J., 1973. Geneza i pozycja stratygraficzna struktur peryglacjalnych w środkowej Polsce. Acta Geographica Lodzienisia 30: 119 pp. (In Polish).

Goździk J.S., French H.M., 2004. Apparent upfreezing of stones in late-Pleistocene coversand, Bełchatów vicinity, Central Poland. Permafrost and Periglacial Processes 15(4): 359-366.

IUSS Working Group WRB, 2006. World Reference Base for Soil Resources. World Soil Resources Reports 103. FAO, Rome: 128 pp.

IUSS Working Group WRB, 2015. World Reference Base for Soil Resources 2014 - an international system for soil classification, first update 2015. World Soil Resources Reports 106. FAO, Rome: $181 \mathrm{pp}$.

Jaworska H., Dąbkowska-Naskręt H., Kobierski M., 2014. The influence of litho- and pedogenic processes on Luvisols formation of selected area of Vistula Glaciation. Geological Quarterly 58(4): 685-694.
Kabała C. (ed.)., 2015. Soils of Lower Silesia: origins, diversity, and protection. PTG, PTSH. Wrocław: 256 pp.

Kacprzak A., Derkowski A., 2007. Cambisols developed from cover-beds in the Pieniny Mts (southern Poland) and their mineral composition. Catena 71(2): 292-297.

Komisarek J., Szałata S., 2008 Textural differentiation in pedons of Albeluvisols in the Wielkopolska Region. Nauka Przyroda Technologie, Melioracje i Inżynieria Środowiska 2: 2-10 (In Polish).

Kondracki J., 2001. Geografia regionalna Polski. Wydawnictwo Naukowe PWN, Warszawa (In Polish).

Konecka-Betley K., 1961. Studies of the sorption complex of soils from boulder loams in relation to their genesis. Soil Science Annual 10(2): 469-524 (In Polish).

Konecka-Betley K., 1979. Reliktowe procesy glebotwórcze w glebach współczesnych wytworzonych z gliny zwałowej. Zeszyty Naukowe SGGW-AR w Warszawie, Rolnictwo 18: 77-95 (In Polish).

Kowalkowski A., Borzyszkowski J., 1977. The role of periglacial and extraperiglacial perstruction in the formation of the soil profile in Central Europe. Folia Quaternaria 49: 25-37.

Kowalkowski A., Prusinkiewicz Z., 1963. Granulometric numeral indieces as indicators of uniformity in Pleistocene sedimental strata. Soil Science Annual 13: 159-162 (In Polish).

Krumbein W.C., 1964. Some remarks on the phi notation. Journal of Sendimentary Petrology 34: 195-196.

Kühn P., 2003. Micromorphology and Late Glacial/Holocene genesis of Luvisols in Mecklenburg-Vorpommern (NE-Germany). Catena 54: 537-555.

Kühn P., Billwitz K., Bauriegel A., Kühn D., Eckelmann W., 2006. Distribution and genesis of Fahlerden (Albeluvisols) in Germany. Journal of Plant Nutrition and Soil Science 169(3): 420-433.

Lindbo D.L., Rhoton F.E., Hudnall W.H., Smeck N.E., Bigham J.M., Tyler D.D., 2000. Fragipan degradation and nodule formation in Glossic Fragiudalfs of the Lower Mississippi River Valley. Soil Science Society of America Journal 64(5): $1713-1722$.

Łabaz B., Bogacz A., Kabała C., 2014. Anthropogenic transformation of soils in the Barycz valley-conclusions for soil classification. Soil Science Annual 65(3): 103-112.

Manikowska B., 1997. Periglacial cover sediments and soil profile evolution on the fluvioglacial interfluve area of Central Poland. Soil Science Annual, 48(3/4): 151-167 (In Polish).

Marcinek J., Komisarek J., 2004. Antropogeniczne przekształcenia gleb Pojezierza Poznańskiego na skutek intensywnego użytkowania rolniczego. Wydawnictwo AR, Poznań, 118 pp. (In Polish).

Mycielska-Dowgiałło E., 1980. Wstęp do sedymentologii. WSP, Kielce, 178 pp. (In Polish).

Polish Soil Classification, 2011. Soil Science Annual 62(3): 1-193 (In Polish).

PTG, 2009. Particle size distribution and textural classes of soils and mineral materials - classification of Polish Society of Soil Sciences 2008. Soil Science Annual 60(2): 6-15 (In Polish).

Racinowski R., Szczypek T., Wach J., 2001. Prezentacja i interpretacja wyników badań uziarnienia osadów czwartorzędowych. Wydawnictwo UŚ, Katowice, 146 pp. (In Polish).

Schoeneberger P.J., Wysocki D.A., Benham E.C., 2012. Field book for describing and sampling soils, Version 3.0. Soil Survey Staff. National Soil Survey Center, Lincoln, NE: 266 pp. 
Schülli-Maurer I., Sauer D., Stahr K., Sperstad R., Sorensen R., 2007. Soil formation in marine sediments and beach deposits of southern Norway: investigations of soil chronosequences in the Oslofjord region. Revista mexicana de ciencias geológicas 24(2): 237-246.

Szałata S., Komisarek J., 2014. Morphological diversity of Arenic Albeluvisols of the Central Wielkopolska Region. Nauka, Przyroda, Technologie 8(4), 55 (In Polish).

Szymański W., Skiba M., Skiba S., 2011. Fragipan horizon degradation and bleached tongues formation in Albeluvisols of the Carpathian Foothills, Poland. Geoderma 167: 340-350.

Świtoniak M., 2008. Classification of young glacial soils with vertical texture-contrast using WRB system. Agrochimija i Gruntoznawstwo 69: 96-01.

Van Ranst E., Dumon M.,. Tolossa A.R, Cornelis J.-T., Stoops G., Vandenberghe R.E., Deckers J., 2011. Revisiting ferrolysis processes in the formation of Planosols for rationalizing the soils with stagnic properties in WRB. Geoderma 163: 265274.
Waroszewski J., Kaliński K., Malkiewicz M., Mazurek R., Kozłowski G., Kabała C., 2013a. Pleistocene-Holocene cover-beds on granite regolith as parent material for Podzols - An example from the Sudeten Mountains. Catena 104: 161-173.

Waroszewski J., Kabała C., Koszelnik K., 2013b. Litological discontinuities in Podzols developed from upper Cretaceous sandstones in the Stołowe Mountains. Prace Geograficzne 135: 87-100 (In Polish).

Zagórski Z., 1995. Micromorphological features of litho- and pedogenic processes in nonuniform soils developed from glacial deposits. Soil Science Annual 46(3/4): 71-93 (In Polish).

Zagórski Z., 1996. Granulometric indices of litho- and pedogenic processes in non-uniform soils developed from glacial deposits. Soil Science Annual 47(supl.): 125-235 (In Polish).

Zagórski Z., 2001 Iron forms as indicators of pedo-and lithogenetic processes in non-uniform soils. Soil Science Annual 52 (supl.): 87-96 (In Polish).

Received: February 9, 2016

Accepted: March 4, 2016

\title{
Uziarnienie gleb płowych zaciekowych spiaszczonych (Albeluvisols, Glossic Planosols) na Dolnym Śląsku
}

\begin{abstract}
Streszczenie: Badaniami objęto gleby płowe zaciekowe spiaszczone (opadowo-glejowe) pokrywające znaczne obszary północno-wschodniej części Dolnego Śląska, w zasięgu występowania glin zlodowacenia Odry i Warty. Celem pracy była charakterystyka uziarnienia gleb w kontekście genezy materiałów macierzystych tych gleb oraz współczesnych procesów glebotwórczych. Wskaźniki sedymentologiczne i granulometryczne, niezbilansowana zawartość frakcji ilastej (i pyłowej), a także obecność bruku morenowego na kontakcie piaszczystych poziomów powierzchniowych oraz gliniastych poziomów podpowierzchniowych wskazują, że zróżnicowanie uziarnienia tych poziomów nie jest efektem procesów pedogenicznych (w szczególności „spiaszczenia” gliny morenowej), ale przede wszystkim wynika z pierwotnej nieciagłości litologicznej materiału macierzystego tych gleb. Uziarnienie i wskaźniki granulometryczne w zaciekach eluwialnych w poziomie glossic wskazują że zacieki nie powstały wyłącznie przez wymycie drobnych frakcji z materiału gliniastego, ale w pierwszej kolejności przez wypełnienie pierwotnych szczelin materiałem piaszczystym. Zacieki eluwialne o grubszym uziarnieniu niż matrix poziomu iluwialnego umożliwiają głębokie wnikanie i stagnowanie wody, a wytwarzające się warunki redukcyjne sprzyjają poszerzaniu i wydłużaniu się zacieków eluwialnych.
\end{abstract}

Słowa kluczowe: gleby płowe zaciekowe, zróżnicowanie uziarnienia, nieciagłość litologiczna 